\begin{tabular}{|l|l|l|}
\hline \multicolumn{2}{|c|}{ PublisherInfo } \\
\hline \hline PublisherName & $:$ & BioMed Central \\
\hline \hline PublisherLocation & $:$ & London \\
\hline \hline PublisherImprintName & $:$ & BioMed Central \\
\hline \hline
\end{tabular}

\title{
Driving man and chimp apart
}

\begin{tabular}{|l|l|l||}
\hline \multicolumn{2}{|c|}{ ArticleInfo } \\
\hline \hline ArticleID & $:$ & 4801 \\
\hline \hline ArticleDOI & $:$ & $10.1186 /$ gb-spotlight-20030626-01 \\
\hline \hline ArticleCitationID & $:$ & spotlight-20030626-01 \\
\hline \hline ArticleSequenceNumber & $:$ & 153 \\
\hline \hline ArticleCategory & $:$ & Research news \\
\hline ArticleFirstPage & $:$ & 1 \\
\hline \hline ArticleLastPage & $:$ & 2 \\
\hline \hline & & RegistrationDate : 2003-6-26 \\
\hline ArticleHistory & $:$ & OnlineDate \\
\hline \hline ArticleCopyright & $:$ & BioMed Central Ltd2003-6-26 \\
\hline \hline ArticleGrants & $:$ & \\
\hline \hline ArticleContext & $:$ & 130594411 \\
\hline \hline
\end{tabular}




\section{Cathy Holding}

Email: cholding@hgmp.mrc.ac.uk

The major histocompatibility locus (MHC) contains some 224 genes and is one of the most genedense regions of the human genome. It comprises the HLA class I and II genes, and contained within the class I region are the MHC class I chain-related (MIC) genes, of which there are two functional coding genes in man, $M I C A$ and $M I C B$. All these genes are highly polymorphic - some having hundreds of alleles within the human population, and a large number function in the immune system. The entire MHC region is highly conserved between chimpanzees (Pan troglodytes) and humans, but these closely related species react quite differently to various pathogens, the most notable being HIV. The entire human MHC genomic sequence is available, and in the June 24 Proc Natl Acad Sci USA, Tatsuya Anzai and colleagues at the Tokai University School of Medicine use probes derived from this to isolate chimpanzee genomic library clones and to derive the genomic sequence of half of the chimpanzee MHC region in order to discover the molecular basis for these immunologic differences (Proc Natl Acad Sci USA, 100:7708-7713, June 24, 2003).

Anzai et al. used comparative genomics to reveal a total of 64 insertion/deletions (indels) $>100 \mathrm{bp}$ long in the human sequence. These are composed of repeat elements and were shown to be directly responsible for the differences between the two species. The most significant of these differences is the loss of one copy of the MIC gene in the chimpanzee, of which there are the two in man. This is not a simple deletion, as occurs in some human individuals carrying the $H L A-B^{*} 4801$ allele, but consists of a similar-sized deletion that joins the $5^{\prime}$ end of human MICA to the $3^{\prime}$ end of $M I C B$, somewhere between $M I C A$ 's second and $M I C B$ 's fourth introns, to create a single chimeric gene in the chimpanzee. In addition, detailed comparison between the $1.87 \mathrm{Mb}$ human and $1.75 \mathrm{Mb}$ chimpanzee sequences revealed that mismatches were represented by $9 \%$ substitutions and by over $90 \%$ indels.

"Comparative genomics with the orthologous human MHC class I region unveils a wealth of information, the most salient being the existence of a large number of indels that appear to be the main driving force behind the observed differences between the two species. Hence our perceived sequence divergence of only $1 \%$ between these two species appears to be erroneous, because this work [...] puts both species much further apart," conclude the authors.

\section{References}

1. MICA and MICB genes: can the enigma of their polymorphism be resolved?

2. Proc Natl Acad Sci USA, [http://www.pnas.org]

3. Tokai University School of Medicine, [http://www.icc.u-tokai.ac.jp/index-e.html] 